\title{
Antioxidant, antimicrobial and cytotoxic activities of silver and gold nanoparticles synthesized using Plumbago zeylanica bark
}

\author{
S. Priya Velammal ${ }^{1}$ T. Akkini Devi ${ }^{1}$ T. Peter Amaladhas ${ }^{1}$
}

Received: 13 April 2016/ Accepted: 1 June 2016/Published online: 13 June 2016

(c) The Author(s) 2016. This article is published with open access at Springerlink.com

\begin{abstract}
Utilization of bioresources for the synthesis of metal nanoparticles is the latest field in green chemistry. The present work reports the utilization of the aqueous bark extract of Plumbago zeylanica for the biosynthesis of $\mathrm{Ag}$ and Au NPs. The Ag and Au NPs thus obtained were characterized by UV-Vis, FT-IR, TEM, XRD, and EDAX analysis. The water-soluble components of the extract were responsible for the reduction of $\mathrm{Ag}^{+}$and $\mathrm{Au}^{3+}$ ions. FT-IR spectra revealed that the $-\mathrm{OH}$ and $>\mathrm{C}=\mathrm{O}$ groups present in the biomolecules were responsible for reduction and stabilization of nanoparticles. TEM images showed the existence of spherical Ag and Au NPs with average size of 28.47 and $16.89 \mathrm{~nm}$, respectively, which was further substantiated by $\mathrm{XRD}$ analysis. The presence of elemental $\mathrm{Ag}$ and $\mathrm{Au}$ along with $\mathrm{C}$ and $\mathrm{O}$ from the attached biomolecules was proved by EDAX analysis. The antimicrobial, antioxidant, and in vitro cytotoxic activities of the synthesized nanoparticles were studied by disc diffusion, DPPH, and MTT assay methods, respectively. The free radical inhibition was found to be 78.17 and $87.34 \%$ for $\mathrm{Ag}$ and $\mathrm{Au}$ nanoparticles, respectively. The Ag and Au NPs showed 61.56 and $65.61 \%$
\end{abstract}

Electronic supplementary material The online version of this article (doi:10.1007/s40097-016-0198-x) contains supplementary material, which is available to authorized users.

T. Peter Amaladhas

peteramaldhast@yahoo.co.in; peteramaladhas@gmail.com

S. Priya Velammal

subraja1950@gmail.com

T. Akkini Devi

t.deviagni@gmail.com

1 PG and Research Department of Chemistry, V.O. Chidambaram College, Tuticorin 628008, Tamil Nadu, India toxicity against DLA cell line, respectively. The DNA binding ability of Ag and Au NPs were investigated using CT-DNA. The hyperchromism shift inferred the groove binding of nanoparticles with CT-DNA.

Keywords Biosynthesis · Silver nanoparticles · Gold nanoparticles · Antioxidant - Cytotoxicity - DLA cell line

\section{Introduction}

Nanoscience and nanotechnology, the two current fields of research have strong and beautiful footprints in ancient times. Nano mercury and its sulfide of sizes finer than $10 \mathrm{~nm}$ have been used as medicines in India since long back [1]. Silver and copper nanoparticles have been used to produce iridescent metallic effects on ancient ceramic objects [2]. The ancient Vedic rite of Agnihotra has used the nanoparticles to cleanse the environment. In Agnihotra, wood of trees like Butea frondosa (palasa), Mangifera indica (mango), Ficus religiosa (pipal), medicinal herbs, ghee, cloves, cardamom, and camphor are offered to the fire god by throwing them into the fire. This has been reported to fill the atmosphere with nutrients in nano size and medicinal properties, which in turn eliminate pathogenic bacteria or germs [3]. In Ayurvedha, herbo-mineral, and herbo-metallic drugs have been prepared by prolonged heating which significantly reduces the particle size. The medicinal use of colloidal gold (Swarnabhasma) and mercury remain popular till this day and the Swarnabhasmas (gold ash) has been characterized as globular particles of gold with the average size between 56 and $57 \mathrm{~nm}$. It has been used to treat arthiritis, asthma, diabetes, and diseases of nervous system [4]. 
Metal and metal oxide nanoparticles have been synthesized using many methods in the past, such as chemical reduction [5], electrochemical reaction [6], microwave method [7], reverse micelles [8], sonochemical method [9], and biosynthesis. Biosynthesis of nanoparticles has received great attention recently as the synthesized nanoparticles are non-toxic and can be used for biomedical applications. Different fungi like Fusarium oxysporum [10], Cladosporium cladosporioides [11], Fusarium semitactum [12], plants like Syzygium aromaticum [13], Medicago sativa [14], Azadirachta indica [15], Terminalia cuneata [16], and Trignellafoenum graecum seeds [17] have been employed to synthesize metal nanoparticles. Recently, sunlight-induced rapid synthesis of silver nanoparticles has been reported by our group [18, 19]. Biosynthesis of silver nanoparticles using bark of Cinnamon zeylanicum [20], Piper nigrum [21], Breynia rhamnoides [22], Avicennia marina [23], Callicarpa maingayi [24], Cissus quadrangularis [25], Artocarpus elasticus [26], and Saraca indica [27] has also been reported. The use of plant barks for the synthesis of nanoparticles avoids the problems that arise due to seasonal variation of biochemicals in the leaves.

Plumbago zeylanica is a medicinal herb belonging to the family of Plumbaginaceae. It has been used as a remedy for skin diseases, ringworm, leprosy, sores, and ulcers. The root or leaves are used as counter-irritant and vesicant. The powdered bark is used to treat leprosy, spleen and liver diseases and also for plaque [28]. It contains a variety of important chemical compounds, such as naphthaquinones, alkaloids, glycosides, steroids, triterpenoids, tannins, phenolic compounds, flavanoids, saponins, coumarins, and carbohydrates [29, 30]. Plumbagin, 5-hydroxy-2-methyl1,4-naphthoquinone is the principal active compound of $P$. zeylanica [31]. In this work, biosynthesis of silver (Ag) and gold (Au) nanoparticles (NPs) was achieved using the bark extract of $P$. zeylanica. The water-soluble biocomponents in the extract not only act as reductants to reduce $\mathrm{Ag}^{+}$and $\mathrm{Au}^{3+}$ to $\mathrm{Ag}^{\circ}$ and $\mathrm{Au}^{\mathrm{o}}$, respectively, but also stabilize them by attaching onto the nanoparticles. The nanoparticles stabilized by active biomolecules may have the potential to treat various diseases. The results of antimicrobial, antioxidant, in vitro cytotoxicity of $\mathrm{Ag}$ and $\mathrm{Au}$ NPs and their ability to bind DNA are reported here.

\section{Methods}

\section{Preparation of bark extract: the reducing agent}

P. zeylanica bark was purchased from the local market from Madurai, Tamil Nadu, India. The bark was finely cut, washed with double-distilled water to remove any impurities and air-dried. About $2 \mathrm{~g}$ of bark was weighed and boiled for $10 \mathrm{~min}$ with $100 \mathrm{~mL}$ distilled water in Erlenmeyer flask. After cooling to room temperature, it was filtered through Whatman no. 41 filter paper. The light yellow colored extract ( $\mathrm{pH}$ 6) was utilized for the synthesis of $\mathrm{Ag}$ and $\mathrm{Au}$ NPs.

\section{Biosynthesis of Ag and Au NPs}

Analar grade silver nitrate $\left(\mathrm{AgNO}_{3}\right)$ with $99.9 \%$ purity was purchased from Spectrochem, India and $99.999 \%$ pure hydrogen tetrachloroaurate(III) trihydrate $\left(\mathrm{HAuCl}_{4}\right.$ $3 \mathrm{H}_{2} \mathrm{O}$ ) was purchased from Sigma-Aldrich, USA. To prepare AgNPs, about $1 \mathrm{~mL}$ of $20-\mathrm{mM} \mathrm{AgNO}_{3}$ was diluted to $20 \mathrm{~mL}$ with double-distilled water and treated with $10 \mathrm{~mL}$ of bark extract, and the solution was exposed to bright sunlight. There was a visible color change from pale yellow to brown in $2 \mathrm{~min}$, and this reaction was monitored with time using UV-Vis spectrophotometer. In the case of AuNPs, $5 \mathrm{~mL}$ of $1-\mathrm{mM} \mathrm{HAuCl}_{4}$ was mixed with $5 \mathrm{~mL}$ of the extract, and the intensity of pink color was monitored with time using UV-Vis spectrophotometer. In both the cases, $1 \mathrm{~mL}$ of the aliquot was diluted to $10 \mathrm{~mL}$ with double-distilled water before measuring the absorbance.

\section{Characterization of Ag and Au NPs}

UV-Vis spectral analysis and DNA binding studies were performed on a JASCO, V-650 spectrophotometer. FT-IR spectra for the dry powder of bark extract and nanoparticles were recorded in the range $4000-400 \mathrm{~cm}^{-1}$ with Thermo scientific, Nicolet iS5 spectrometer. The size of the nanoparticles was assessed using PHILIPS, CM 200, TEM microscope operated at $200 \mathrm{kV}$ with a resolution of $2.4 \AA$. The diffraction pattern of nanoparticles was recorded using a PANalytical X'Pert Powder X'Celerator diffractometer, with $\mathrm{CuK} \alpha$ monochromatic filter. To ascertain the elemental composition of $\mathrm{Ag}$ and $\mathrm{Au}$ NPs, energy dispersive X-ray (EDAX) analysis was performed on a JEOL, Model JED-2300 microscope. Ultrasonic probe sonicator, Enertech make, model: ENUP-500A was used to disperse CTDNA in Tris- $\mathrm{HCl}$ buffer solution.

\section{Antimicrobial activity}

Kirby-Bauer disc diffusion method was employed to assess the antimicrobial activity of biosynthesized $\mathrm{Ag}$ and $\mathrm{Au}$ NPs. The bacteria Escherichia coli, Pseudomonas aeruginosa, Bacillus subtilis, and Staphylococcus aureus, and the fungi Candida tropicalis and Aspergillus flaves were chosen for study. For disc diffusion method, the bacterial inoculums were standardized to a density equivalent to barium sulfate standard of 0.5 McFarland units and 
swabbed into petridish of $4 \mathrm{~mm}$ depth. About $2 \mathrm{~mm}$ loopful of extract, $\mathrm{Ag}$ and Au NPs were taken and lowered carefully onto the paper disc. The moistened disc was then placed on the surface of inoculated plate and incubated for $16-18 \mathrm{~h}$ at $35-37^{\circ} \mathrm{C}$. Netilmicin and fluconazole were used as controls for bacteria and fungi, respectively.

\section{Antioxidant activity}

Antioxidant activity of the synthesized Ag and Au NPs was assessed using DPPH assay. From the stock solution of the nanoparticles $(1 \mathrm{mg} / \mathrm{mL})$, samples containing 50, 100, 150, and $200 \mu \mathrm{g}$ were prepared and mixed with $0.1 \% \mathrm{DPPH}$. The reaction mixture was incubated for $30 \mathrm{~min}$ at room temperature. When DPPH reacts with any antioxidant, it gets reduced, and the intensity of color decreases; and the decrease in absorbance at $517 \mathrm{~nm}$ was recorded, and butylated hydroxytoluene (BHT) was used as a standard control. The experiment was performed in triplicate, and the scavenging activity was calculated as \% inhibition according to the following formula, where, $A$ is absorbance.

$\%$ Inhibition $=100$

$$
\times \frac{(A \text { of standard control }-A \text { of sample })}{A \text { of standard control }}
$$

\section{In vitro cytotoxicity of Ag and Au NPs}

Cytotoxic effect was determined by tetrazolium dye (3(4,5-Dimethylthiazol-2-yl)-2,5-diphenyltetrazolium bromide)-based microtitration assay (MTT assay) against DLA (Dalton Lymphoma Ascites) cell lines. Cells were maintained in Dulbecco's modified Eagle's medium (DMEM) supplemented with $10 \%$ fetal bovine serum (FBS) at $37^{\circ} \mathrm{C}$ in humidified atmosphere with $5 \% \mathrm{CO}_{2}$. The cells were seeded in 96-well flat-bottom tissue culture plates at a density of approximately $1.2 \times 10^{4}$ cells per well and were allowed to attach overnight at $37^{\circ} \mathrm{C}$. Cells were exposed to plant extract, $\mathrm{Ag}$ and $\mathrm{Au}$ NPs over a range of concentration for $24 \mathrm{~h}$. After the incubation, medium was discarded; the MTT (10 $\mu \mathrm{L}$ of $5 \mathrm{mg} / \mathrm{mL})$ was added to $100 \mu \mathrm{L}$ of fresh medium and was incubated for additional $4 \mathrm{~h}$. MTT assay was based on the measurement of the mitochondrial activity of viable cells by the reduction of the tetrazolium salt (MTT) to form a blue water-insoluble product, formazan. After $4 \mathrm{~h}$ of incubation, the medium was discarded, and $100 \mu \mathrm{L}$ of DMSO was added to dissolve the formazan crystals, which were formed by the reduction of tetrazolium salt only by metabolically active cells [32]. The absorbance assay plates were measured at $570 \mathrm{~nm}$ in a micro-titer plate reader. Since the absorbance was directly correlated with the number of viable cells, cell survival was calculated by the following formula:

$\%$ viability $=\frac{A_{t}}{A_{c}} \times 100$

where, $A_{t}$ is the absorbance of sample and $A_{c}$ is the absorbance of control. Percentage cytotoxicity is calculated by the formula: cytotoxicity $\%=100-\%$ viability.

\section{DNA binding studies}

In every organism, deoxyribonucleic acid (DNA) is an important genetic substance. The study of interaction of drug and DNA has acquired great significance for designing and synthesizing new drugs targeted at DNA. Presuming biomolecules capped nanoparticles as drug, the ability to bind DNA was investigated. UV-Visible spectral studies were employed to study the binding of $\mathrm{Ag}$ and $\mathrm{Au}$ NPs with Calf-thymus DNA (CT-DNA). DNA solutions were prepared using the buffer $5 \mathrm{mM}$ Tris- $\mathrm{HCl} / 50 \mathrm{mM}$ $\mathrm{NaCl}$ at $\mathrm{pH}=7.2$ in water and sonicated for 30 cycles, where each cycle consisted of $1 \mathrm{~min}$ with $30 \mathrm{~s}$ interval; which gave ratio of absorbance at 260 and $280 \mathrm{~nm}, \mathrm{~A} 260 /$ A280 as 1.87 . This ratio indicates that the DNA was sufficiently free of protein. Absorption spectra were recorded at fixed-concentration $\mathrm{Ag}$ and $\mathrm{Au} \mathrm{NPs}$ for varying concentration of the CT-DNA $(2-10 \mu \mathrm{g} / \mathrm{mL})$ or vice versa. Stock solutions of DNA were stored at $4{ }^{\circ} \mathrm{C}$ and used in 4 days.

\section{Results and discussion}

\section{Parameters influencing the formation of AgNPs}

The effect of time, volume of extract, concentration of metal precursors and $\mathrm{pH}$, which influence the formation of AgNPs were studied in detail, and the results are presented here.

\section{Effect of time}

The mixture of the extract and silver nitrate solution was exposed to sunlight, and the SPR band was monitored in regular intervals using UV-Vis spectrophotometer. The color of the solution changed from yellow to dark brown in $2 \mathrm{~min}$, the intensity of the color increased with time and finally attained a constant value in $40 \mathrm{~min}$ implying that the formation of AgNPs is almost complete (Fig. 1a). The decrease in peak width and the shift in $\lambda_{\max }$ from 426 to $416 \mathrm{~nm}$ with time infer that the formation of monodispersed and small-sized nanoparticles, respectively [33]. 


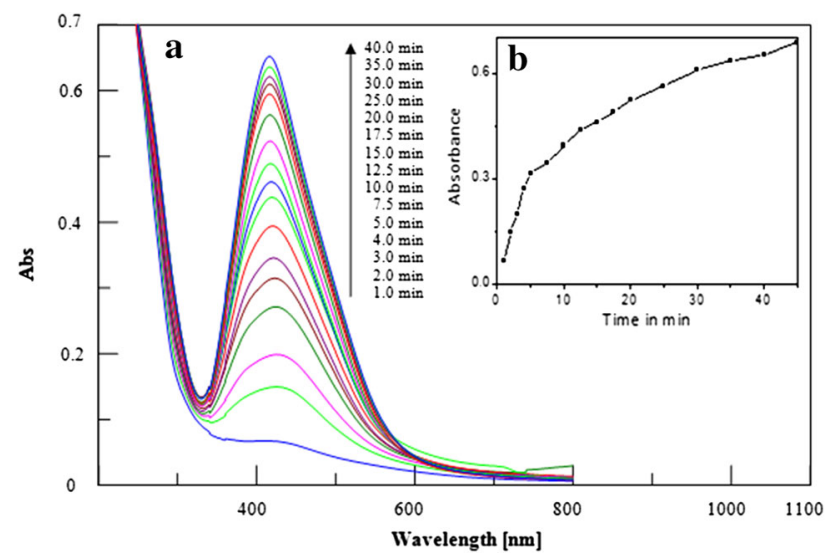

Fig. 1 a UV-Vis spectra of the mixtures of the extract and $\mathrm{AgNO}_{3}$ with time b Variation of absorbance with time

\section{Influence of extract volume}

To assess the effect of concentration of extract on the formation of AgNPs, the volume was varied from 1 to $15 \mathrm{~mL}$ by maintaining the total volume of the reaction mixture as constant $(20 \mathrm{~mL})$. The solutions were then exposed to sunlight for $10 \mathrm{~min}$, and the UV-Visible spectra were recorded. The intensity of the SPR band around $449 \mathrm{~nm}$ increased with increase in the volume of extract up to $10 \mathrm{~mL}$, accompanied by a blue shift in $\lambda_{\max }$ from 449 to $417 \mathrm{~nm}$ (Fig. 2a). This infers that size of nanoparticles decreases with increase in concentration of extract (reducing agent). When the volume of extract exceeds $10 \mathrm{~mL}$, decrease in the absorbance was noticed (Fig. 2b), maybe due to the aggregation of nanoparticles. Other researchers [34] have also reported this trend in biosynthesis of AgNPs. Narrow peaks were obtained for higher volume of extract implying the formation of smaller sized AgNPs.

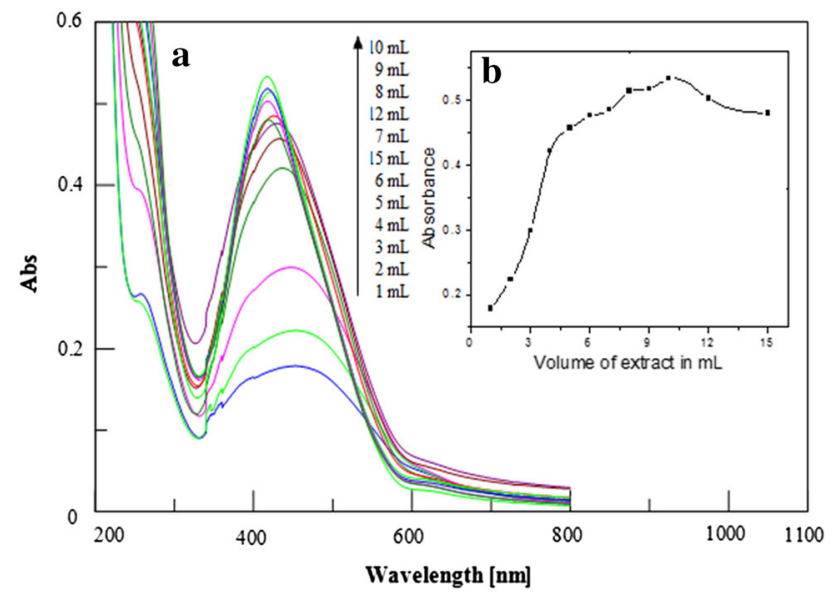

Fig. 2 a UV-Visible spectra of reaction mixture at various volume of extract b Change in absorbance with volume of extract
Influence of concentration of silver nitrate

To optimize the concentration of $\mathrm{AgNO}_{3}$ required for the synthesis of stable AgNPs, it was varied from 1 to $10 \mathrm{mM}$, and after exposing the solutions to sunlight for $10 \mathrm{~min}$, the SPR band was monitored. With increase in concentration of $\mathrm{AgNO}_{3}$, there was a red shift in SPR band from 418 to $442 \mathrm{~nm}$ (Fig. 3a) indicating the increase of particle size. At further high concentrations $(5-8 \mathrm{mM})$, the metallic silver got deposited on the sides of the flask as the silver mirror and the absorbance of the reaction mixture had decreased consequently (Fig. 3b). On further increase of $\mathrm{Ag}^{+}$ion concentration $(9$ and $10 \mathrm{mM}$ ), a black precipitate was obtained, maybe due to formation of $\mathrm{Ag}_{2} \mathrm{O}$ (results not shown).

\section{Effect of $p H$}

The AgNPs were synthesized over a wide $\mathrm{pH}$ range $(\mathrm{pH}$ 2-11) using 0.1-M sulphuric acid or 0.1-M sodium hydroxide. In acidic $\mathrm{pH}$, large-sized nanoparticles were formed, while in alkaline $\mathrm{pH}$, small-sized nanoparticles were produced, as indicated by blue shift in $\lambda_{\max }$ from 420 to $413 \mathrm{~nm}$ (Fig. 4a). In alkaline $\mathrm{pH}$, many functional groups are ionized and are available for reduction and facilitate the formation of small size nanoparticles. The $\mathrm{pH}$ of the extract was 6 , and stable nanoparticles were formed in this condition, and hence, all experiments were carried out at this $\mathrm{pH}$ unless otherwise mentioned.

\section{UV-Visible spectral analysis of AuNPs}

The AuNPs synthesized using $P$. zeylanica were analyzed by UV-Visible spectrophotometer, where SPR band was observed at $542 \mathrm{~nm}$. The formation of AuNPs was so quick; the color of solution turns red with pink tinge within

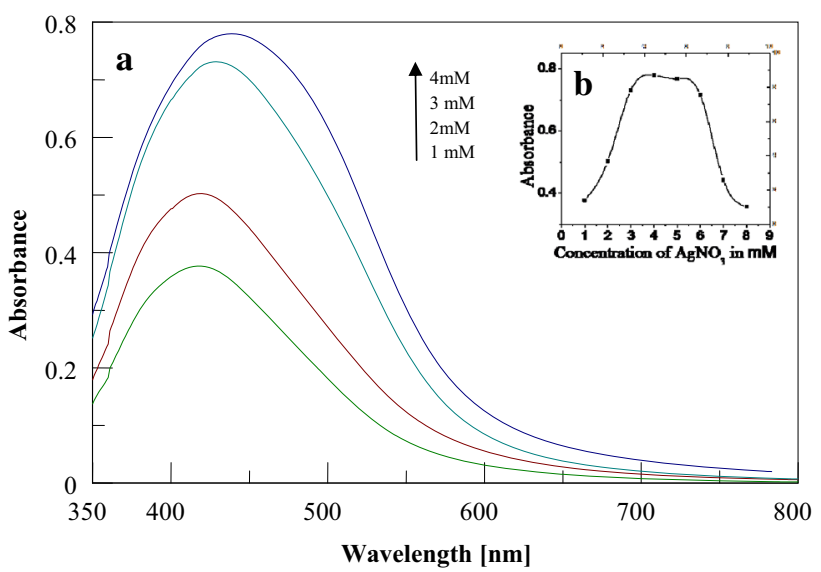

Fig. 3 a UV-Visible spectra of AgNPs at varying concentration of $\mathrm{AgNO}_{3} \mathbf{b}$ Variation of absorbance with concentration of silver nitrate 


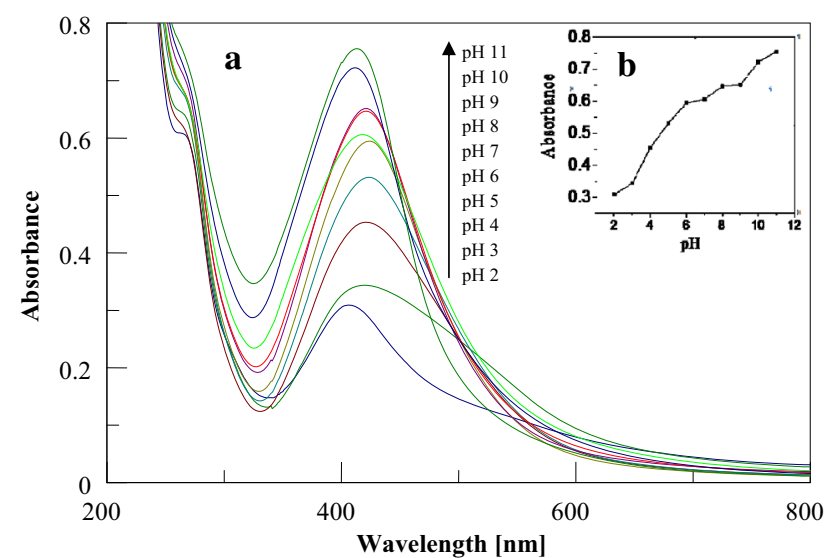

Fig. 4 a UV-Visible spectra of AgNPs synthesized at various $\mathrm{pH}$ b Variation of absorbance with $\mathrm{pH}$

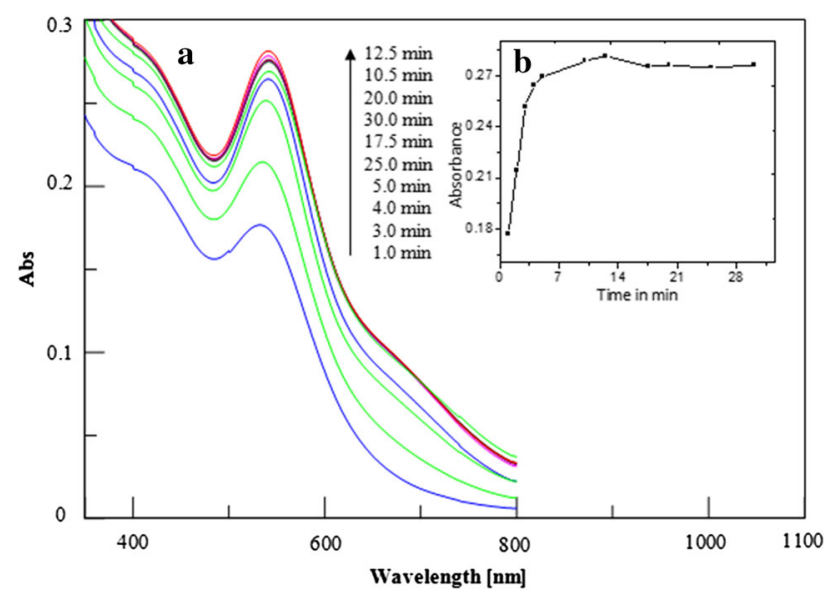

Fig. 5 a UV-Visible spectra of the synthesized AuNPs as a function of time b Variation of absorbance with time

the time of mixing, and the absorbance became constant within $10 \mathrm{~min}$ indicating the completion of the reaction (Fig. 5b). No appreciable shift in the SPR band was observed with time, and the narrow SPR band indicates the formation of monodispersed AuNPs.

\section{FT-IR studies}

FT-IR spectra of Ag and Au NPs were recorded to identify the possible biomolecules responsible for the reduction and capping. The Ag and Au nanosolutions were centrifuged at $13000 \mathrm{rpm}$ for $15 \mathrm{~min}$ and air-dried. This dried powder was made as pellets with $\mathrm{KBr}$, and the spectra were recorded. Figure 6 shows the FT-IR spectra of the bark extract, Ag and Au NPs. The spectrum of extract (powder) has peaks at 1063,1384 , and $1631 \mathrm{~cm}^{-1}$. The AgNPs have peaks at 1033,1384 , and $1615 \mathrm{~cm}^{-1}$, while AuNPs exhibits peaks at 1032, 1383, and $1602 \mathrm{~cm}^{-1}$. The main peaks present in the extract are also present in both $\mathrm{Ag}$ and $\mathrm{Au}$
NPs inferring that the attachment of biomolecules which are present in the extract to nanoparticles.

Different plant parts of $P$. zeylanica contain naphthaquinones, alkaloids, glycosides, steroids, triterpenoids, tannins, phenolic compounds, flavanoids, coumarins, carbohydrates, saponins, proteins, oils, and fats [29]. Of all the chemical constituents, plumbagin is the principle active compound. Plumbagin (5-hydroxy-2-methyl-1,4-naphthoquinone $-\mathrm{C}_{11} \mathrm{H}_{8} \mathrm{O}_{3}$ ) is primarily present in roots in higher amounts. The structures of plumbagin, glycoside and derivatives of glycoside are represented below [35]. The major water-soluble components present in $P$. zeylanica extract are glycosides [36].<smiles>CC1=CC(=O)c2c(O)cccc2C(=O)C1=O</smiles>

The peak at $1631 \mathrm{~cm}^{-1}$ in extract gets shifted to 1615 and $1602 \mathrm{~cm}^{-1}$ in the spectra of $\mathrm{Ag}$ and $\mathrm{Au}$ NPs, respectively. This peak corresponds to chelated $>\mathrm{C}=\mathrm{O}$ group [37], inferring that the binding of biomolecules with the nanoparticles through this group. The peaks at 3424, 3420, and $3384 \mathrm{~cm}^{-1}$ in the spectra of the extract, Ag and Au NPs are due to $-\mathrm{OH}$ groups in the biocomponents, and they may be responsible for bioreduction. The peaks near $2912 \mathrm{~cm}^{-1}$ in all the three spectra are due to $-\mathrm{C}-\mathrm{H}$ stretching of aromatic ring. Further, the peaks at $1033 \mathrm{~cm}^{-1}$ and $1032 \mathrm{~cm}^{-1}$ in the spectra of $\mathrm{Ag}$ and $\mathrm{Au}$ NPs, respectively, which appears as shoulder in extract, correspond to $\mathrm{C}-\mathrm{O}$ stretching frequency of biocomponents. These data indicate the involvement of $>\mathrm{C}=\mathrm{O}$ and $-\mathrm{OH}$ functional groups in the reduction and stabilization of nanoparticles.

\section{Mechanism of formation and stabilization of AgNPs}

The phytoconstituents like plumbagin and hydroplumbagin glucoside contain many hydroxyl groups. On addition of bark extracts to the $\mathrm{AgNO}_{3}$ solution, the $\mathrm{Ag}^{+}$- phytoconstituent complex is formed as an intermediate. The nascent hydrogens produced during this process reduce $\mathrm{Ag}^{+}$to $\mathrm{Ag}^{\mathrm{O}}$ followed by coalescence, cluster formation, and growth of clusters, finally yielding AgNPs [38]. The phenolic groups present in the bark extract subsequently undergo oxidation and get converted to their quinone forms. The electrochemical potential difference between $\mathrm{Ag}^{+}$and phytoconstituents drives the reaction. The formed AgNPs are stabilized through the lone pair of electrons and $\pi$ electrons of quinone structures (Scheme 1). 


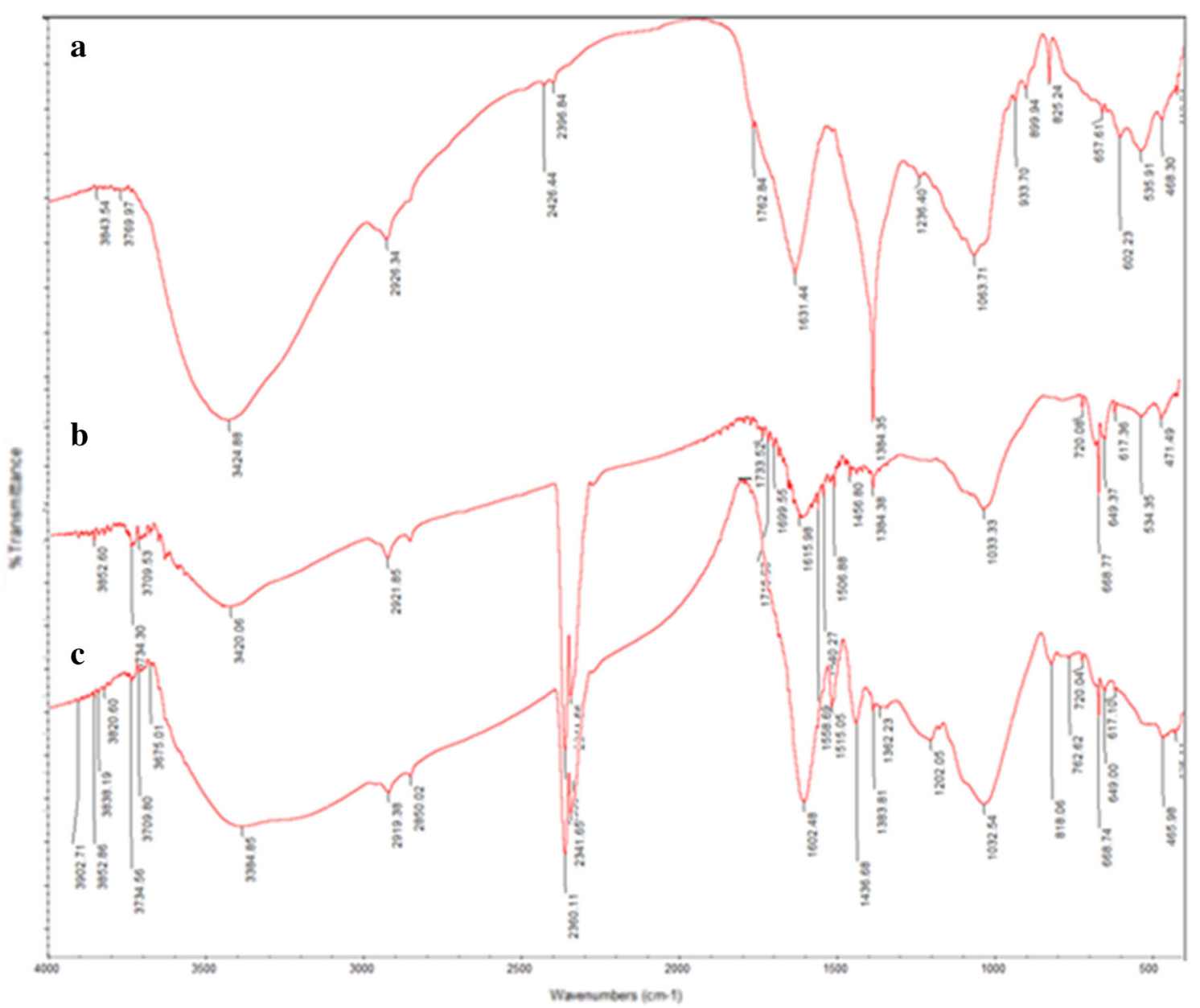

Fig. 6 FT-IR spectra of a Plumbago zeylanica bark extract, b AgNPs and c AuNPs

\section{TEM studies}

TEM analysis reveals the size and morphology of biosynthesized NPs. TEM images of the Ag and Au NPs at different magnification are depicted in Figs. 7 and 8, respectively. The TEM images clearly show that the nanoparticles are predominantly spherical in shape. The size is in the range of $2.76-51.57 \mathrm{~nm}$ (average size $28.47 \mathrm{~nm}$ ) for AgNPs and 10-25 nm (average size $16.89 \mathrm{~nm}$ ) for AuNPs. Figures $7 \mathrm{~d}$ and $8 \mathrm{~d}$ show the SAED patterns (circular rings) of $\mathrm{Ag}$ and $\mathrm{Au}$ NPs, that reveal the crystalline nature of nanoparticles. The diffraction rings arise due to reflections of planes of fcc crystals which is evinced from broad Bragg's reflection observed in the XRD spectra.

\section{XRD studies}

X-ray diffraction patterns of the Ag and Au NPs are shown in Fig. 9a, b, respectively. A comparison of XRD pattern of AgNPs with the standard JCPDS file no. 89-3722 [39] confirms the crystalline face-centered cubic (fcc) nature, as evidenced by the peaks at $2 \theta$ values of $37.99^{\circ}, 64.52^{\circ}$, and $76.69^{\circ}$, which can be indexed to 111,220 , and 311 planes, respectively. AuNPs show similar characteristic peaks of metallic fcc gold (JCPDS: 4-0784) [27]. The particle sizes of $\mathrm{Ag}$ and $\mathrm{Au}$ NPs were computed by Debye-Scherrer equation from which the average size was found to be 17.26 and $12.84 \mathrm{~nm}$, respectively.

$\mathrm{D}=k \lambda / \beta \cos \theta$

where, $\mathrm{k}$ is the Scherrer constant, $\lambda$ is the wavelength of the $\mathrm{X}$-ray, $\beta$ and $\theta$ are the half-width of the peak and half of the Bragg angle, respectively.

\section{EDAX analysis}

EDAX (Energy Dispersive X-ray) analysis was performed to confirm the elemental form of silver and gold. Figure 10a represents the EDAX profile of AgNPs. The EDAX spectrum shows a strong signal at $3 \mathrm{keV}$, which corresponds to metallic nanosilver [40]; peak 


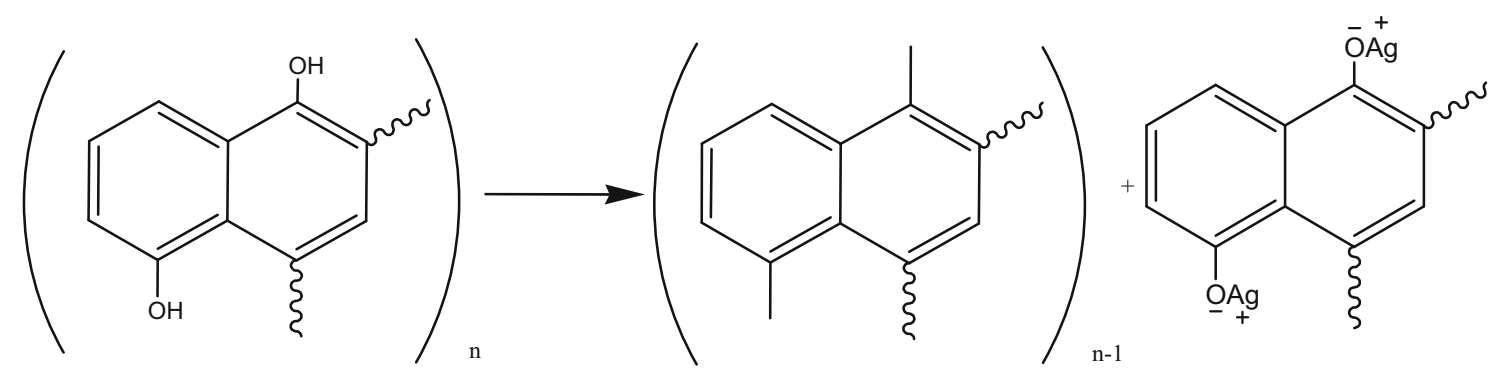<smiles>O=[N+]([O-])c1cccc2c([18O])c([125I])cc([18OH])c12</smiles><smiles>CC=C1C=CCC2=C1CC=CC2=O</smiles>

Scheme 1 Mechanism of reduction of $\mathrm{Ag}^{+}$to $\mathrm{Ag}^{\mathrm{o}}$

Fig. 7 TEM images (ac) AgNPs (d) SAED pattern
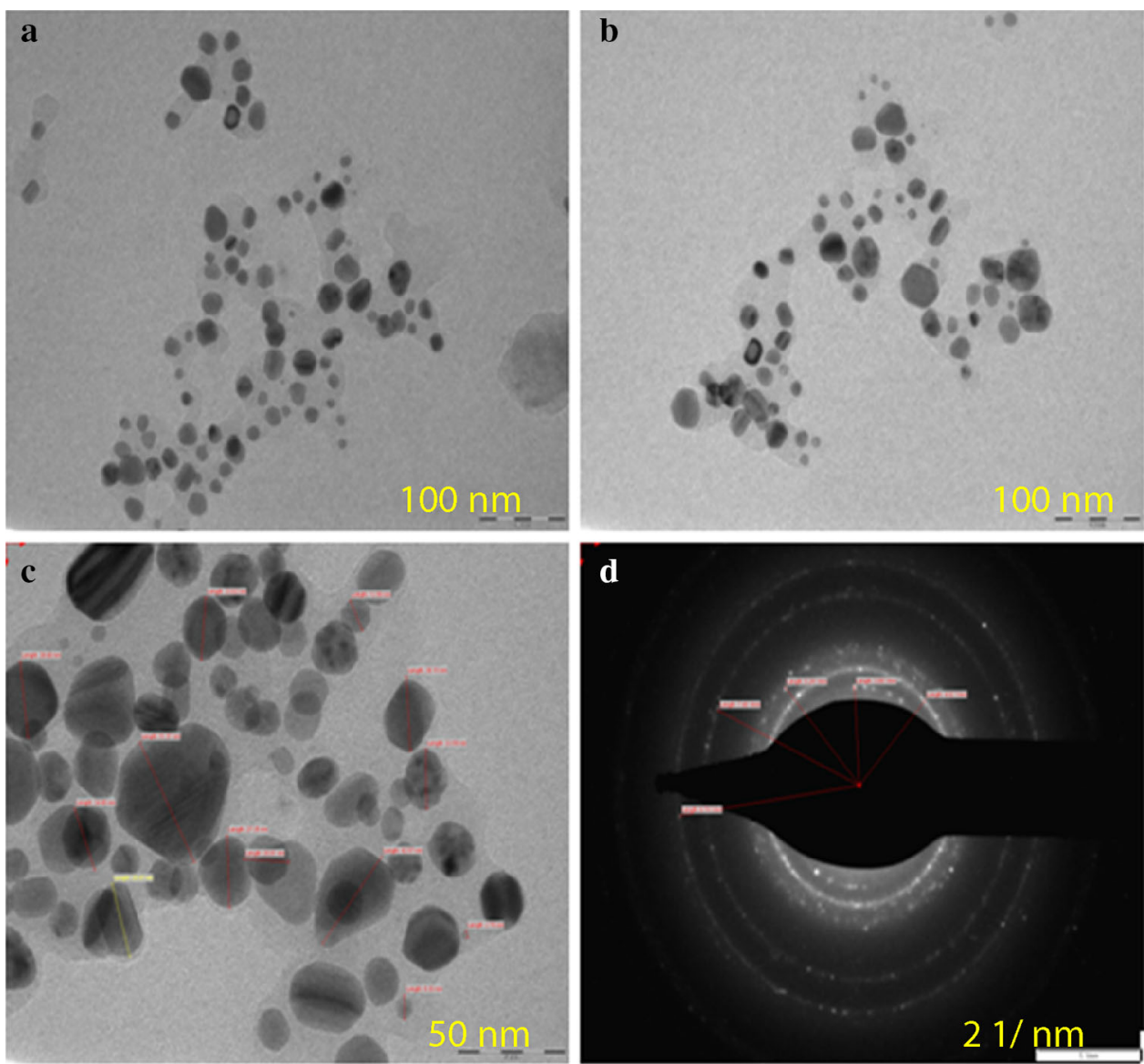

corresponding to $\mathrm{Cl}^{-}$impurity is also present in the spectrum. There are also weak signals for carbon and oxygen, possibly due to the biocomponents attached to
AgNPs. Figure 10b represents EDAX profile of AuNPs, which has strong signals around 2 and $10 \mathrm{keV}$, which correspond to metallic nanogold [41]. There are also 
Fig. 8 TEM images of (ac) AuNPs d SAED pattern
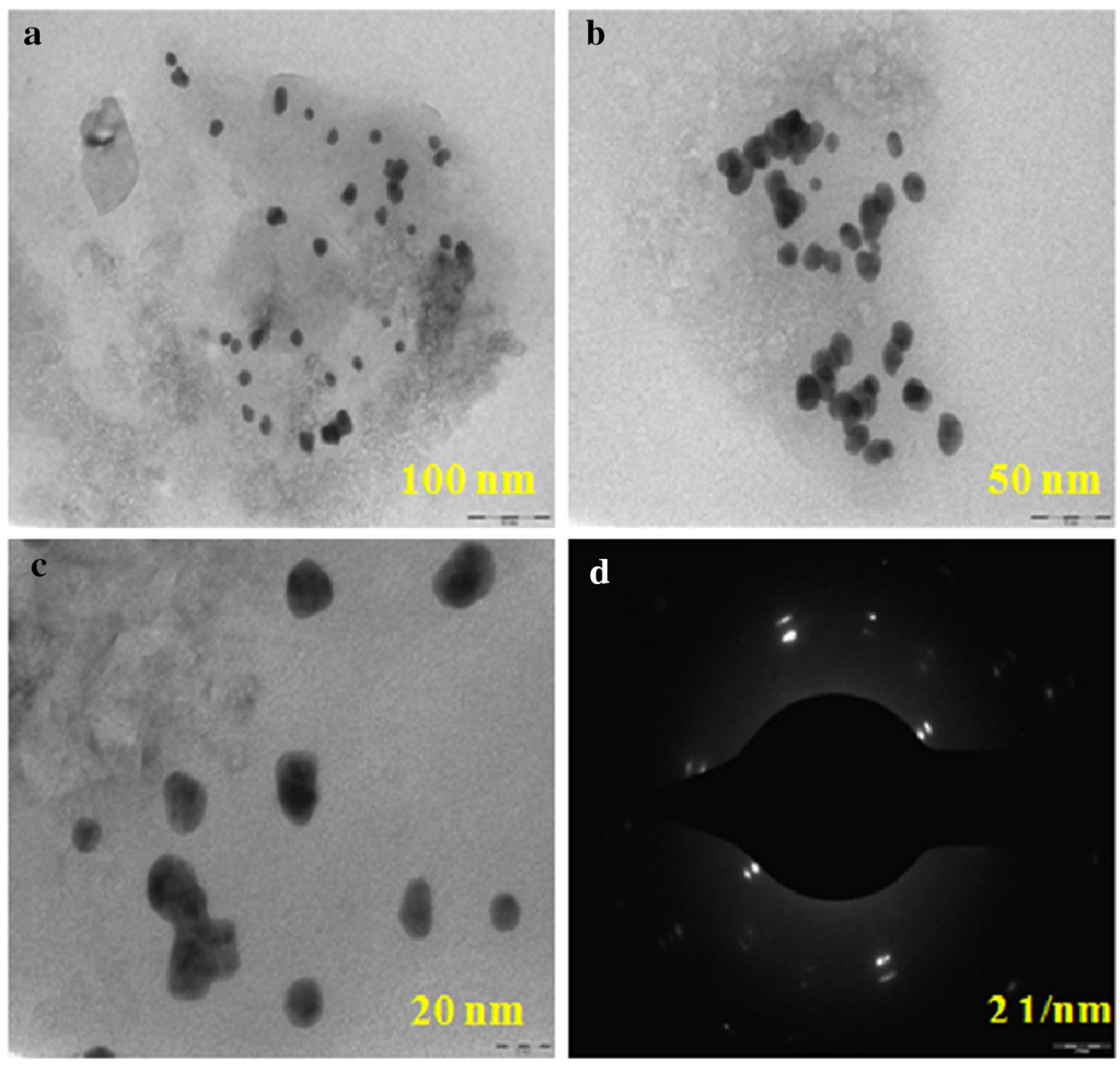

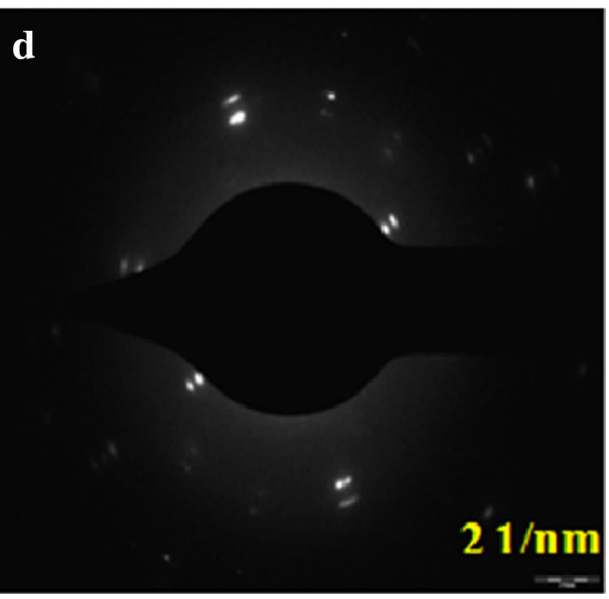

weak signals for carbon and oxygen, indicating capping of AuNPs by biocomponents from the plant extract.

\section{Antimicrobial activity}

The AgNPs have desirable activity against Bacillus subtilis (12 $\mathrm{mm})$ and Pseudomonas aeruginosa $(11 \mathrm{~mm})$, but the zone of inhibition for Staphylococcus aureus, Candida tropicalis, E.Coli was $8 \mathrm{~mm}$ each; for Aspergillus flaves no inhibition was observed (Fig. 11). The extract and AuNPs have no effect on any of the species.

\section{Antioxidant activity using DPPH assay}

Antioxidants protect cells against damaging effects of reactive oxygen species, which can neutralize free radicals before they can do harm and undo some damage already caused to specific cells. Medicinal plants contain many free radical scavenging molecules like phenolic compounds and vitamins. $P$. zeylanica contains a variety of important chemical compounds and, hence, expected to be a potential antioxidant. DPPH (2,2-diphenyl-1-picryl- hydrazyl) assay method was adopted to study the antioxidant activity of the synthesized $\mathrm{Ag}$ and $\mathrm{Au}$ NPs. Substances which are capable of reducing DPPH free radical are radical scavengers and considered to be antioxidants [42]. DPPH is a stable nitrogen-centered free radical with a purple color. When it reacts with an antioxidant, which can donate an electron to DPPH radical, it changes to a stable compound (DPPH-H) with yellow color [43]. As a consequence, purple color decays can be monitored through UV spectrophotometer at $517 \mathrm{~nm}$.

The percentage inhibition of free radicals is presented in Fig. 12. Free radical scavenging activity increases with increasing the concentration of extract, $\mathrm{Ag}$ and $\mathrm{Au}$ NPs. At $200 \mu \mathrm{g} / \mathrm{mL}$ concentration, extract inhibits $71.16 \%$ of free radicals, whereas, AuNPs, AgNPs, and standard BHT exhibit 87.34, 78.17, and 74.88\% inhibition, respectively. At this concentration, the antioxidant activity decreases in the order: AuNPs $>$ AgNPs $>$ extract $>$ standard BHT. The results are appreciable when compared with the previous report [44]. The $\mathrm{IC}_{50}$ values for $\mathrm{Au}$ and $\mathrm{Ag}$ NPs are higher than standard BHT (Table S1). 
Fig. 9 XRD pattern of a AgNPs b AuNPs

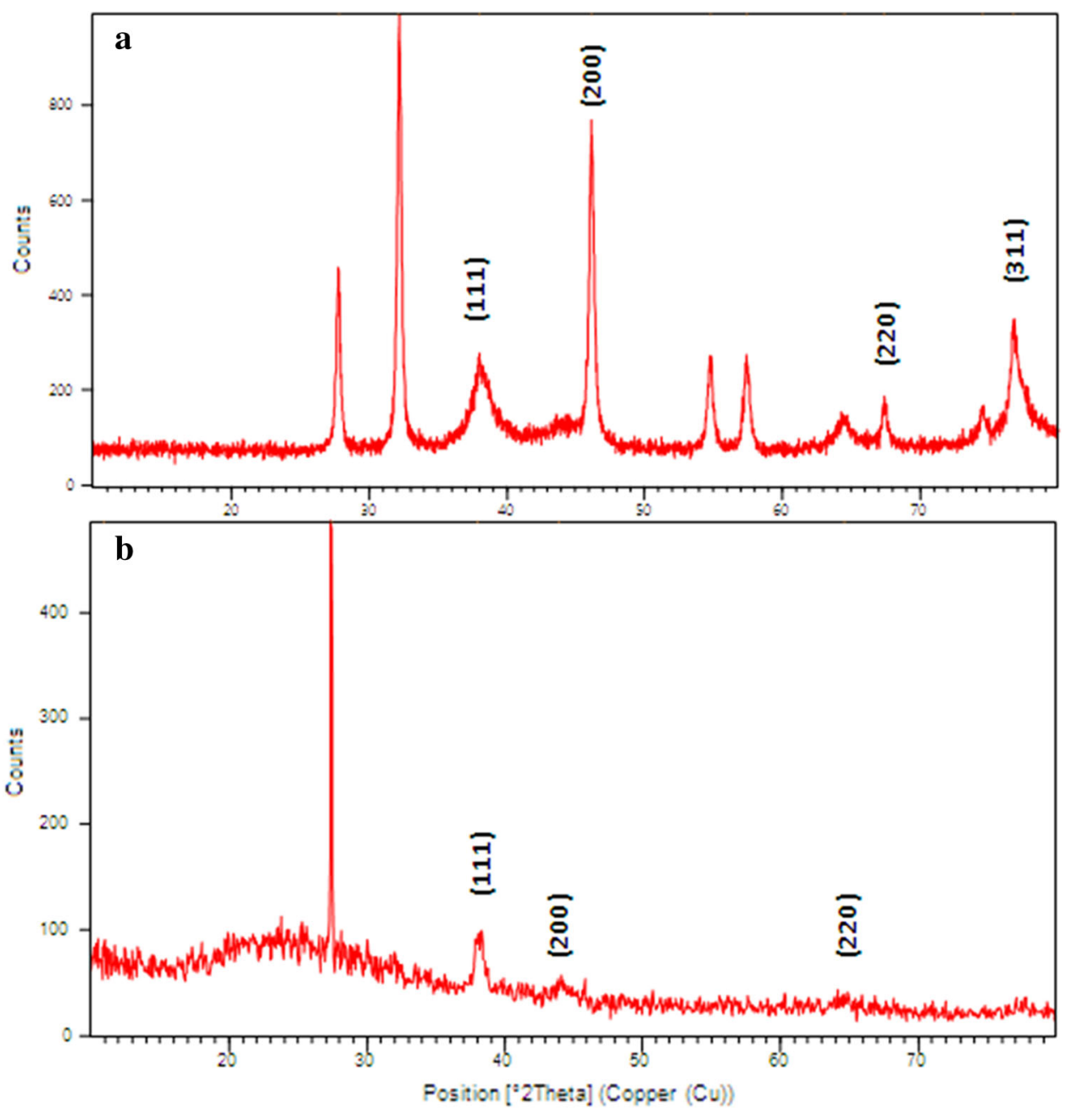

\section{In vitro cytotoxicity against DLA cell line}

Only live cells reduce the tetrazolium dye but not the dead cells. When MTT is reduced, the quaternary amine is converted into a tertiary amine by opening the tetrazolium ring. A second tertiary amine, which is formed, binds to a hydrogen atom of the quarternary amine. The absorption spectrum of the molecule changes as a result of the displacement of this hydrogen atom at high $\mathrm{pH}$. Subsequently, the cell numbers can be estimated. Thus, absorbance is directly correlated to number of viable cells [45].

The percentage cell toxicity of extract, Ag and Au NPs, against DLA cell line is given in the Fig. 13. The data reveal that the increase in concentration of extract increases the toxicity. While comparing the results with other studies, it is obvious that the higher toxicity is observed in aqueous extract, whereas in previous reports, other solvent extracts were found to have higher toxicity [46]. At $150 \mu \mathrm{g} / \mathrm{mL}$ concentration, the extract, $\mathrm{Au}$ and $\mathrm{Ag}$ NPs exhibit 58.35, 61.56, and $65.61 \%$ toxicity, respectively (Table S2). One interesting observation is that the extract itself shows considerable toxicity against DLA cell line. This may be due to the presence of plumbagin, which is reported to be a potent anticancer drug [47].

\section{DNA binding studies}

Nucleic acids show a strong absorbance in the region of $240-275 \mathrm{~nm}$. It originates from the $\pi \rightarrow \pi^{*}$ transitions of the pyrimidine and purine ring systems of the nucleobases. The bases can be protonated, and therefore, the spectra of DNA and RNA are sensitive to $\mathrm{pH}$. At neutral $\mathrm{pH}$, the absorption maxima range from $253 \mathrm{~nm}$ (for guanosine) to $271 \mathrm{~nm}$ (for cytidine); as a consequence, polymeric DNA and RNA show a broad and strong absorbance near $260 \mathrm{~nm}$.

Electronic spectroscopy is one of the useful techniques to study the binding of DNA with small molecules. Small molecules can react with DNA via covalent or non-covalent interactions. For non-covalent interactions, generally there are three modes for binding viz. electrostatic attractions with the anionic sugar-phosphate backbone of DNA, 
Fig. 10 EDAX spectrum of a AgNPs b AuNPs
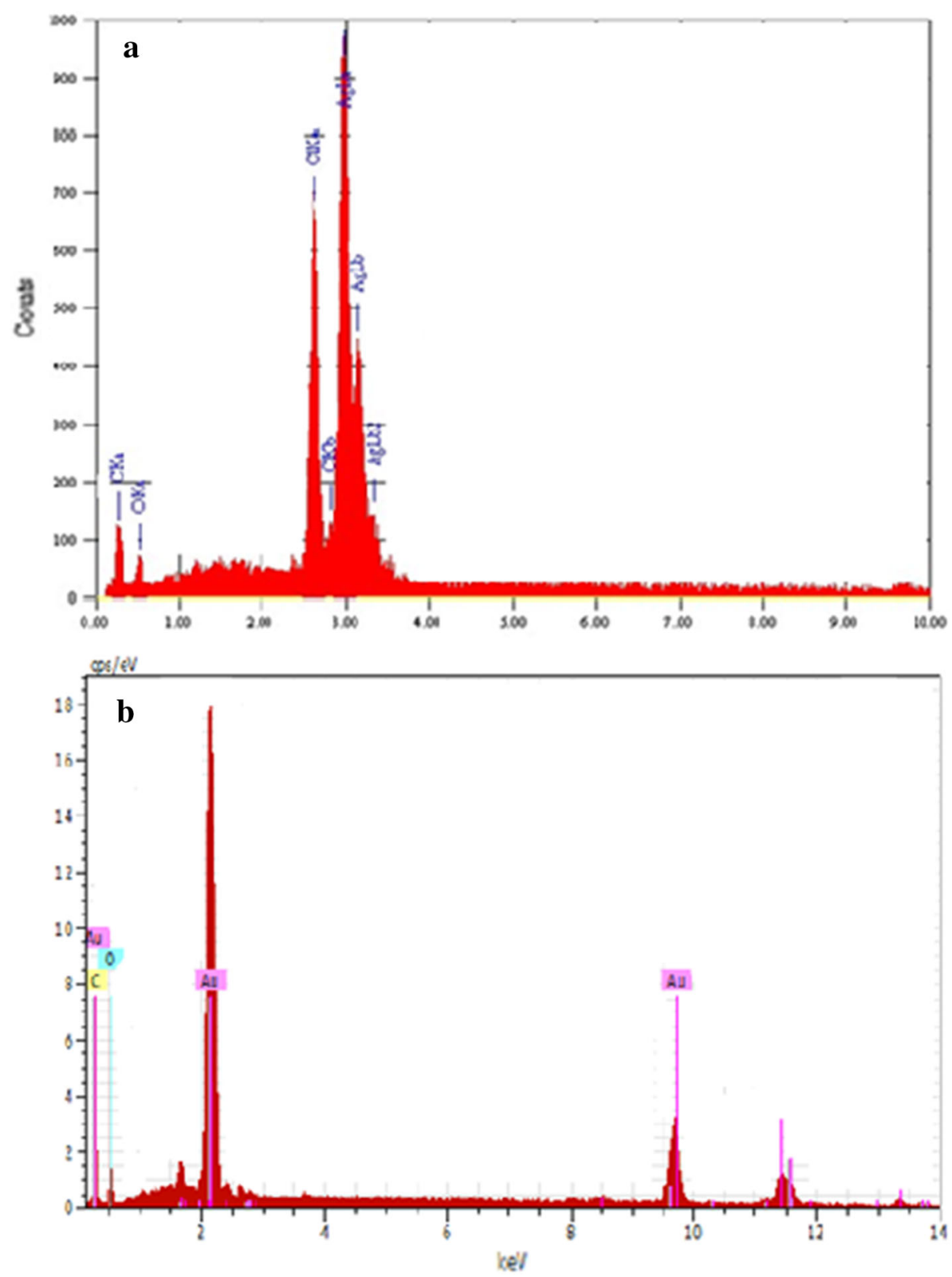

interactions with the DNA groove, and intercalation between base pairs through DNA groove [48]. The absorption spectra of CT-DNA with the increase in concentration of Ag and Au NPs are given in Figs. 14 and 15. The increase of absorption intensity (hyperchromism) at $258 \mathrm{~nm}$ (due to $\pi \rightarrow \pi^{*}$ transition of sugar phosphate in DNA) with increase in concentration of Ag and Au NPs indicates the interaction of the nanoparticles with DNA. In general, DNA exhibits both hyper and hypochromism in the electronic spectrum. Hypochromism suggests the interaction of small molecules with DNA through intercalation, and hyperchromism suggests that the interaction is through groove binding; moreover, hyperchromism is an indication of the breakage of secondary structure of DNA
[49]. The values of the binding constant, $\mathrm{K}_{\mathrm{app}}$ are obtained from absorbance values as reported in the literature [50]. For weak binding affinities, the data are examined by linear reciprocal plots based on the following equation:

$\frac{1}{A_{\mathrm{obs}}-A_{o}}=\frac{1}{A_{c}-A_{o}}+\frac{1}{\mathrm{~K}_{\mathrm{app}}\left(A_{c}-A_{0}\right)[\mathrm{AgNPs}]}$

where $A_{o}$ is the absorbance of CT-DNA in the absence of AgNPs, and $A_{c}$ is the recorded absorbance of CT-DNA for different concentration of AgNPs. The double reciprocal plot of $1 / A_{\mathrm{obs}}-A_{O}$ vs $1 /[\mathrm{AgNPs}]$ is linear (Fig. 14a), and the binding constant $\left(\mathrm{K}_{\mathrm{app}}\right)$ can be calculated from the ratio of intercept to slope. $\mathrm{K}_{\mathrm{app}}$ is found to be $7.03 \times 10^{7}$ and $1.15 \times 10^{7}$ for $\mathrm{Ag}$ and Au NPs using the above equation. 

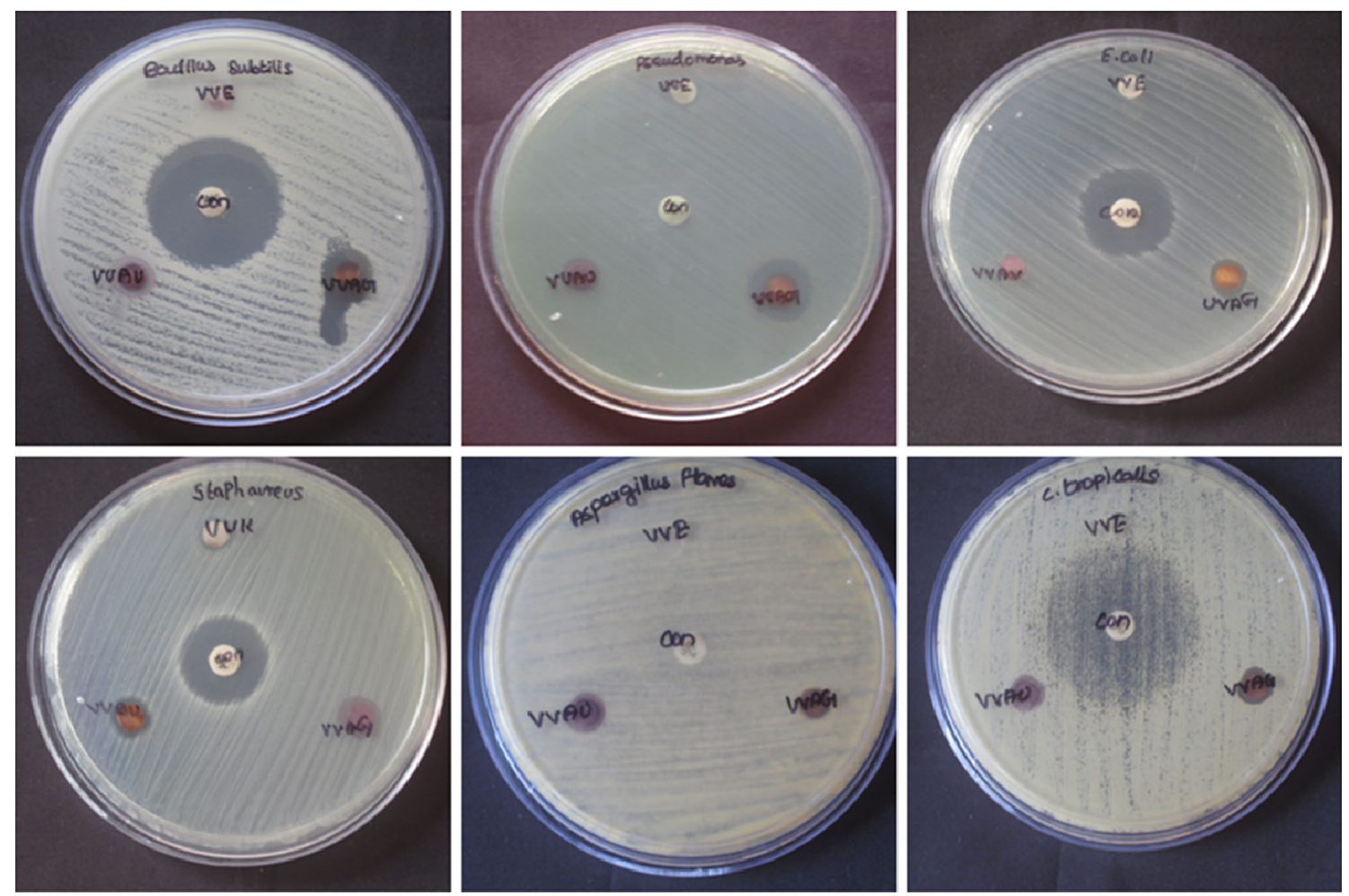

Fig. 11 Antibacterial activity of Plumbago zeylanica extract (VVE), AgNPs (VVAG), and AuNPs (VVAU)

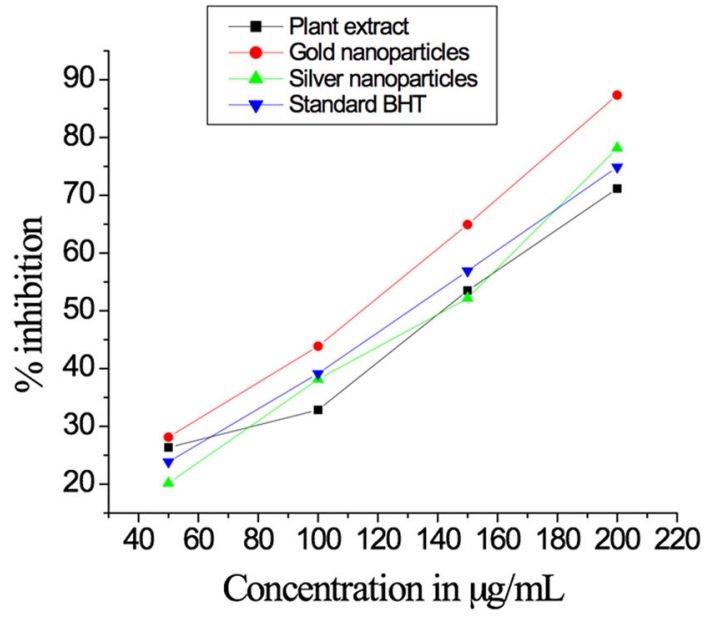

Fig. 12 Antioxidant activity of plant extract and that of $\mathrm{Ag}$ and $\mathrm{Au}$ NPs

The binding constant values are high when compared to normal intercalators [51], which further support groove binding. The intensity of the SPR band also increased with the increase in concentration of Ag and Au NPs.

Electronic spectra were also recorded for different concentration of CT-DNA at fixed concentration of Ag and Au NPs (Figs. S3 and S4). No appreciable increase in absorbance was noticed with varying concentration of CTDNA.

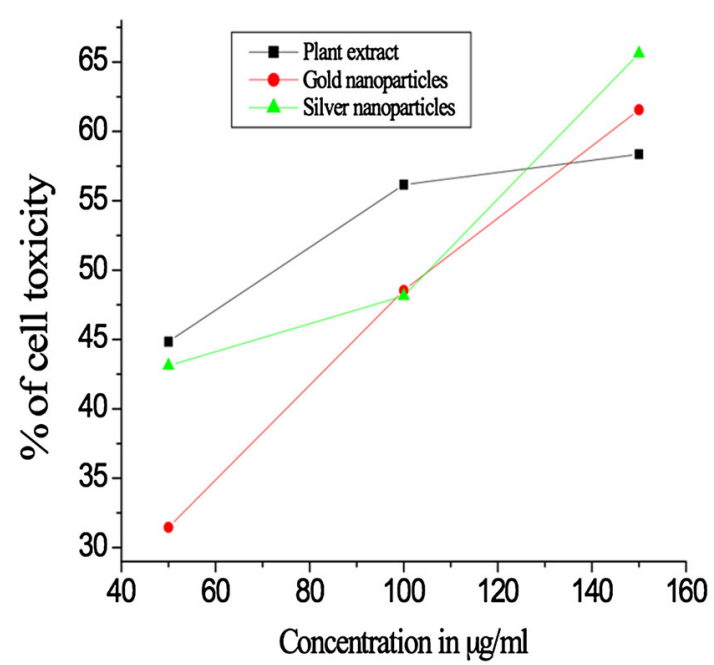

Fig. 13 In vitro cytotoxicity of extract, $\mathrm{Ag}$ and $\mathrm{Au}$ NPs

\section{Conclusions}

Bioreductive synthesis of Ag and Au NPs using a medicinally important plant Plumbago zeylanica, yielded spherical nanoparticles with average size of 28.47 and $16.89 \mathrm{~nm}$, respectively. AgNPs have desirable antibacterial activity against Bacillus subtilis and Pseudomonas aeruginosa in comparison to plant extract and AuNPs. Ag and Au NPs 


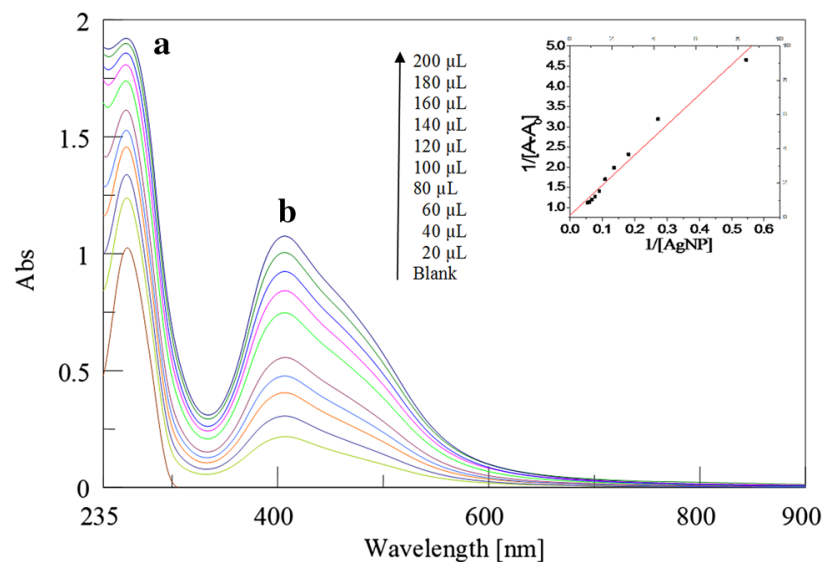

Fig. 14 Absorption spectra of (a) CT-DNA with varying concentration of (b) AgNPs; Insert: Plot of $1 /\left[A_{\mathrm{obs}}-A_{0}\right]$ vs $1 /[\mathrm{AgNP}]$

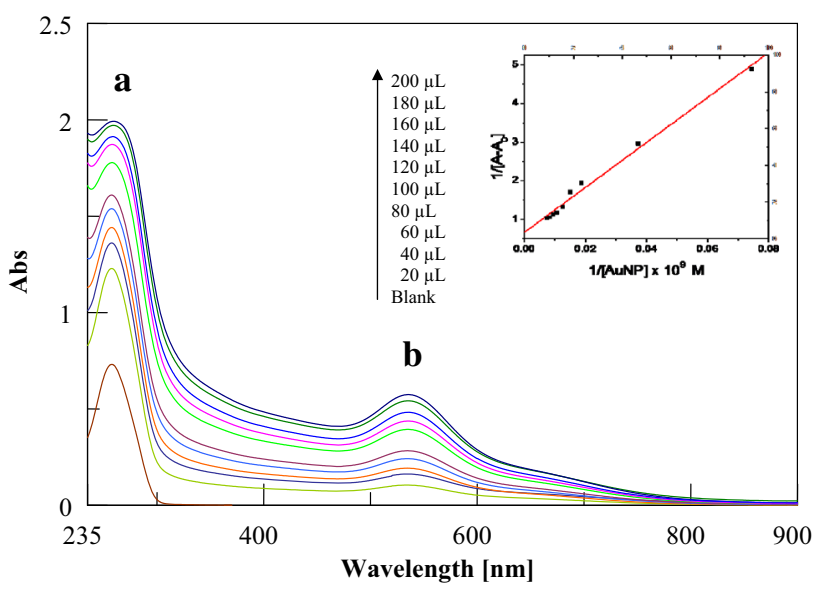

Fig. 15 Absorption spectra of (a) CT-DNA with varying concentration of (b) AuNPs; Insert: Plot of $1 /\left[A-A_{O}\right]$ vs $1 /[$ AuNPs]

have potential antioxidant activity, and the percentage of inhibition of free radicals is found to be 78 and $87 \%$, respectively. In vitro cytotoxicity studies showed that $\mathrm{Ag}$ and Au NPs have 65 and $61 \%$ of toxicity against DLA cell lines. The aqueous extract shows enhanced cytotoxicity in comparison with previous reports. Binding of $\mathrm{Ag}$ and $\mathrm{Au}$ NPs with CT-DNA is demonstrated by UV-Visible spectrophotometry. The hyperchromism in absorbance suggests the groove binding of these NPs with CT-DNA. The data presented in this study may contribute to the development of nanomaterials as an alternative drug to treat cancer.

Acknowledgments This work is Sponsored by University Grants Commission (UGC), New Delhi. The authors, S. Priya @ Velammal thanks UGC for Minor Research Project and T. Akkini Devi thanks UGC for Project Fellowship. Dr. M.A. Neelakantan, Dean of National Engineering College, Kovilpatti, Tamil Nadu is acknowledged for his help in DNA binding studies. The authors thank Dr. Samasun fertility lab services, Tirupur, Tamil Nadu and Dr. V. R. Mohan, PG and Research Department of Botany, V.O.C. College for their help in antioxidant and cytotoxic studies. SAIF, IIT Bombay, India is acknowledged for TEM analysis.

Open Access This article is distributed under the terms of the Creative Commons Attribution 4.0 International License (http://crea tivecommons.org/licenses/by/4.0/), which permits unrestricted use, distribution, and reproduction in any medium, provided you give appropriate credit to the original author(s) and the source, provide a link to the Creative Commons license, and indicate if changes were made.

\section{References}

1. Padhi, P., Sahoo, G., Gosh, S., Das, K., Panigrahi, S.C.: Synthesis of black and red mercury sulfide nano-powder by traditional indian method for biomedical application. AIP Conf. Proc. 1063, 431-438 (2008)

2. Fermo, P., Padeleeti, G.: The use of nanoparticles to produce iridescent metallic effects on ancient ceramic objects. J. Nanosci. Nanotechnol. 12, 8764-8769 (2012)

3. Satish Kapoor, K.: Nanoconcept in Indian tradition. Dav's Ayurveda Holist. Health Mag. 1, 22 (2012)

4. Arvizo, R.R., Bhattacharyya, S., Kudgus, R.A., Giri, K., Bhattacharya, R., Mukherjee, P.: Intrinsic therapeutic applications of noble metal nanoparticles: past, present and future. Chem. Soc. Rev. 41, 2943-2970 (2012)

5. Nikhil, R.J., Latha, G., Catherine, J.M.: Wet chemical synthesis of high aspect ratio cylindrical gold nanorods. J. Phys. Chem. B. 105, 4065-4067 (2001)

6. Rodriguez, S.L., Blanco, M.C., Lopez Quintela, M.A.: Electrochemical synthesis of silver nanoparticles. J. Phys. Chem. B 104, 9683-9686 (2009)

7. Pastoriza, S., Liz Marzan, L.M.: Preparation of PVP-protected metal nanoparticles in DMF. Langmuir 18, 2888-2895 (2002)

8. Noritomi, H., Umezawa, Y., Miyagawa, S., Kato, S.: Preparation of highly concentrated silver nanoparticles in reverse micelles of sucrose fatty acid esters through solid-liquid extraction method. Adv Chem Eng Sci 1, 299-304 (2011)

9. Zhu, J.J., Liu, S.W., Palchik, O., Koltypin, Y., Gedanken, A.: Shape-controlled synthesis of silver nanoparticles by pulse sonoelectrochemical methods. Langmuir 16, 6396-6399 (2000)

10. Ahmad, A., Mukherjee, P., Senapati, S., Mandal, D., Islam Khan, M., Kumar, R., Sastry, M.: Extracellular biosynthesis of silver nanoparticles using the fungus Fusarium oxysporum. Colloids Surf. B 28, 313-318 (2003)

11. Balaji, D.S., Basavaraja, S., Raghunandan, D., Mahesh, B., Prabhakar, B.K., Venkataraman, A.: Extracellular biosynthesis of functionalized silver nanoparticles by strains of Cladosporium cladosporioides fungus. Colloids Surf. B 68, 88-92 (2009)

12. Basavaraja, S., Balaji, D.S., Lagashetty, A., Rajasab, A.H., Venkataraman, A.: Extracellular biosynthesis of silver nanoparticles using the fungus Fusarium semitectum. Mater. Res. Bull. 43, 1164-1170 (2008)

13. Raghunandan, D., Basavaraja, S., Mahesh, B., Balaji, S., Manjunath, S.Y., Venkataraman, A.: Rapid biosynthesis of irregular shaped gold nanoparticles from macerated aqueous extracellular dried clove buds (Syzygium aromaticum) Solution. Colloids Surf. B 79, 235-240 (2010)

14. Gardea Torresdey, L.J., Gomez, E., Peralta Videa, R.J., Parsons, J.G., Troiani, H., Jose Yacaman, M.: Alfalfa sprouts: a natural source for the synthesis of silver nanoparticles. Langmuir 19, 1357-1361 (2003) 
15. Shankar, S.S., Rai, A., Ahmad, A., Sastry, M.: Rapid synthesis of $\mathrm{Au}, \mathrm{Ag}$, and bimetallic $\mathrm{Au}$ Core- $\mathrm{Ag}$ shell nanoparticles using neem (Azadirachta Indica) leaf broth. J. Colloid Interface Sci. 275, 496-502 (2004)

16. Jebakumar, T., Lee, Y.R., Sethuraman, M.G.: Green synthesis of silver nanoparticles using Terminalia cuneata and its catalytic action in reduction of direct yellow-12 dye. Spectrochim. Acta Part A Mol. Biomol. Spectrosc. 161, 122-129 (2016)

17. Vidhu, V.K., Philip, D.: Catalytic degradation of organic dyes using biosynthesized silver nanoparticles. Micron 56, 54-62 (2014)

18. Peter Amaladhas, T., Usha, M., Naveen, S.: Sunlight induced rapid synthesis and kinetics of silver nanoparticles using leaf extract of Achyranthes aspera L. and their antimicrobial application. Adv. Mat. Lett. 4, 779-785 (2013)

19. Akkini Devi, T., Ananthi, N., Peter Amaladhas, T.: Photobiological synthesis of noble metal nanoparticles using Hydrocotyle asiatica and application as catalyst for the photodegradation of cationic dyes. J. Nanostruct. Chem. 6, 75-92 (2016)

20. Sathishkumar, M., Sneha, K., Won, S.W., Cho, C.W., Kim, S., Yun, Y.S.: Cinnamon zeylanica bark extract and powder mediated green synthesis of nano-crystalline silver particles and its bactericidal activity. Colloids Surf B Biointerfaces 73, 332-338 (2009)

21. Paulkumar, K., Gnanajobitha, G., Vanaja, M., Rajeshkumar, S., Malarkodi, C., Pandian, K., Annadurai, G.: Piper nigrum leaf and stem assisted green synthesis of silver nanoparticles and evaluation of its antibacterial activity against agricultural plant pathogens. Sci World J 2014, 1-9 (2014)

22. Gangula, A., Podila, R., Ramakrishna, M., Karanam, L., Janardhana, C., Rao, A.M.: Catalytic reduction of 4-Nitrophenol using biogenic gold and silver nanoparticles derived from Breynia rhamnoides. Langmuir 27, 15268-15274 (2011)

23. Gnanadesigan, M., Anand, M., Ravikumar, S., Maruthupandy, M., Syed Ali, M., Vijayakumar, V., Kumaraguru, K.: Antibacterial potential of biosynthesised silver nanoparticles using Avicennia marina mangrove plant. Appl. Nanosci. 2, 143-147 (2012)

24. Kamyar, S., Mansor Bin, A., Emad, A.J., Ibrahim, N.A., Parvaneh, S., Abdolhossein, R., Yadollah, A., Samira, B., Sanaz, A., Muhammad, S.U., Mohammed, Z.: Green biosynthesis of silver nanoparticles using Callicarpa maingayi stem bark extraction. Molecules 17, 8506-8517 (2012)

25. Santhoshkumar, T., Rahuman, A.A., Bagavan, A., Marimuthu, S., Jayaseelan, C., Kirthi, A.V., Kamaraj, C., Rajakumar, G., Zahir, A.A., Elango, G., Velayutham, K., Iyappan, M., Siva, C., Karthick, L.: Bhaskara Rao, K.V.: Evaluation of stem aqueous extract and synthesized silver nanoparticles using Cissus quadrangularis against Hippobosca maculate and Rhipicephalus (Boophilus) microplus. Exp. Parasitol. 132, 156-165 (2012)

26. Abdullah, N.I.S.B., Ahmad, M.B., Shameli, K.: Biosynthesis of silver nanoparticles using Artocarpus elasticus stem bark extract. Chem. Cent. J. 9, 61 (2015)

27. Shib Shankar, D., Rakhi, M., Arun Kanti, S., Braja Gopal, B., Biplab Kumar, P.: Saraca indica bark extract mediated green synthesis of polyshaped gold nanoparticles and its application in catalytic reduction. Appl. Nanosci. 4, 485-490 (2014)

28. Tilak, J.C., Adhikari, S., Devasagayam, T.P.A.: Antioxidant properties of Plumbago zeylanica, an Indian medicinal plant and its active ingredient, plumbagin. Redox Rep. 9, 219-227 (2004)

29. Ming, Y., Wang, J., Yang, J., Liu, W.: Chemical constituents of Plumbago zeylanica. Adv. Mater. Res. 308, 1662-1664 (2011)

30. Kapoor, L.D.: Handbook of Ayurvedic medicinal plants. CRC Press, London (1990)

31. Krishnaswamy, M., Purusothaman, K.K.: Plumbagin: a study of its anticancer, antibacterial and antifungal properties. Indian J. Exp. Biol. 18, 876-877 (1980)
32. Sarah Brown, D., Paola, N., Jo-Ann, S., David, S., Paul, E.R., Balaji, V., David Flint, J., Jane Plumb, A., Duncan, G., NialWheate, J.: Gold nanoparticles for the improved anticancer drug delivery of the active component of oxaplatin. J. Am. Chem. Soc. 132, 4678-4684 (2010)

33. Sheny, D.S., Mathew, J., Philip, D.: Phytosynthesis of Au, Ag and $\mathrm{Au}-\mathrm{Ag}$ bimetallic nanoparticles using aqueous extract and dried leaf of Anacardium occidentale. Spectrochemica Acta Part A 79, 254-262 (2011)

34. Muhammad, A., Farooq, A., Muhammad Ramzan, S.A.J., Muhammad, A.I., Umer, R.: Green synthesis of silver nanoparticles through reduction with Solanum Xanthocarpum $L$. berry extract: characterization, antimicrobial and urease inhibitory activities against Helicobacter pylori. Int. J. Mol. Sci. 13, 9923-9941 (2012)

35. Zhang, O.R., Mei, Z.N., Yang, G.Z., Xiao, Y.X.: Chemical constituents from aerial parts of Plumbago zeylanica Linn. J. Chin. Med. Mater. 30, 558-560 (2007)

36. Navneet, K., Bhuwan Mishra, B., Vinod Tiwari, K., Vyasji, T.: An account of phytochemicals from Plumbago zeylanica (Family: Plumbaginaceae): A natural gift to human being. Chron. Young Sci. 3, 178 (2012)

37. Lie Chwen, L., Ling Lang, Y., Cheng Jen, C.: Cytotoxic naphthaquinones and plumbagic acid glucosides from Plumbago zeylanica. Phytochemistry 62, 619-622 (2003)

38. Emrah, B., Mahmut, O.: Rapid, facile synthesis of silver nanostructure using hydrolysable tannin. Ind. Eng. Chem. Res. 48, 5686-5690 (2009)

39. Kasi, G., Shanmugam, G., Ayyakannu, A.: Phytosynthesis of silver nanoparticles using Pterocarpus santalinus leaf exract and their antibacterial properties. J. Nanostruct. Chem. 3, 68 (2013)

40. Nyoman Rupiasih, N., Avinash, A., Suresh, G., Vidyasagar, P.B.: Green synthesis of silver nanoparticles using latex extract of Thevetia peruviana: a novel approach towards poisonous plant utilization. J. Phys. Conf. Ser. 423, 12032-12039 (2013). doi:10. 1088/1742-6596/423/1/012032

41. Narayanan, K.B., Sakthivel, N.: Phytosynthesis of gold nanoparticles using leaf extract of Coleus amboinicus Lour. Mater. Charact. 61, 1232-1238 (2010)

42. Sharad, M., Prachi, B., Man Mohan, S.: Enhanced antioxidant activity of gold nanoparticle embedded 3,6-dihydroxyflavone: a combinational study. Appl. Nanosci. 4, 153-161 (2014)

43. Elena, H.N., Miron, C.T., Gabriela, P., Mihaela, H., Titus, C., Alexandru, B.T.: Reaction of 2,2-diphenyl-1-picrylhydrazyl with $\mathrm{HO}, \mathrm{O}_{2}{ }^{-}, \mathrm{HO}^{-}$and $\mathrm{HOO}^{-}$radicals and anions. Int. J. Mol. Sci. 7, 130-143 (2006)

44. Veerapandian, S., Sawant, S.N., Dobie, M.: Antibacterial and Antioxidant activity of protein capped silver and gold nanoparticles synthesized with Escherichia coli. J. Biomed. Nanotechnol. 8, 140-148 (2012)

45. Berridge, M.V., Herst, P.M., Tan, A.S.: Tetrazolium dyes as tools in cell biology: new insights into their cellular reduction. Biotechnol. Annu. Rev. 11, 127-152 (2005)

46. Krishnaraj, C., Muthukumaran, P., Ramachandran, R., Balakumaran, M.D., Kalaichelvan, P.T.: Acalypa indica Linn: biogenic synthesis of silver and gold nanoparticles and their cytotoxic effects against MDA-MB-231, human breast cancer cells. Biotechnol. Rep. 4, 42-49 (2014)

47. Jordan Sand, M., BilalBin, H., Mohammad, S.J., Olya, W., Emily, M.S., Joseph, F., Ajit, K.V.: Plumbagin (5-hydroxy-2methyl-1,4-naphthoquinone), isolated from Plumbago zeylanica, inhibits ultraviolet radiation-induced development of squamous cell carcinomas. Carcinogenesis 33, 184-190 (2011)

48. Yunhua, W., Guangzhong, Y.: Interaction between Garcigenrin and DNA by spectrophotometry and fluorescence spectroscopy. Spectrosc. Lett. 43, 28-35 (2010) 
49. Nahid, S., Saba, H.: Spectroscopic studies on the interaction of calf thymus DNA with the drug levetiracetam. Spectrochim. Acta Part A Mol. Biomol. Spectrosc. 96, 278-283 (2012)

50. Swarup, R., Ratan, S., Utpal, G., Tapan, K.D.: Interaction studies between biosynthesized silver nanoparticle with calf thymus DNA and cytotoxicity of silver nanoparticles. Spectrochim. Acta Part A Mol. Biomol. Spectrosc. 141, 176-184 (2015)
51. Pin-xian, X., Zhi-hong, X., Feng-juan, C., Zheng-zhi, Z., Xiaowen, Z.: Study on synthesis, structure and DNA binding of Ni, Zn complexes with 2-phenylquinoline-4 carboylhydrazide. J. Inorg. Biochem. 103, 210-218 (2009) 